\title{
OS MEIOS EXECUTIVOS ATÍPICOS E A PROPORCIONALIDADE
}

\author{
José Leite dos Santos Neto* \\ Ubirajara Coelho Neto**
}

\begin{abstract}
Resumo: O diagnóstico da ineficácia do processo executivo por dados do CNJ e, fulcrado na previsão expressa das formas executivas atípicas no inciso IV, art. 139 do CPC, analisando a aplicação da regra da proporcionalidade doutrinada por Robert Alexy sobre os pressupostos e situações ensejadoras dessas novas formas, defendemos que esse instituto deve passar a ser visto como regra e não mais como exceção nos processos ou fases de execução ou nos executivos fiscais. Essa mudança de postura deve superar a cultura do inadimplemento, sob pena de a jurisdição perder legitimidade social.
\end{abstract}

Palavras-chaves: meios executivos atípicos; proporcionalidade; Justiça em números.

\section{THE ATYPICAL EXECUTIVE FORMS AND THE PROPORCIONALITY}

Abstract: The diagnosis of the inefficiency of the executive process by CNJ data and, fulfilled in the express prediction of the atypical executive forms in subsection IV, art. 139 of the CPC, analyzing the application of the rule of proportionality indoctrinated by Robert Alexy on the presuppositions and situations leading to these new forms, we argue that this institute should be seen as a rule and no longer as an exception in the processes or stages of execution or executives tax authorities. This change of position must overcome the culture of default, otherwise the jurisdiction loses social legitimacy.

Keywords: atypical executive media; proportionality; Justice in Numbers.

\section{1 - INTRODUÇÃO}

Desde a edição da Emenda Constitucional 45, de 30 de dezembro de 2004 e a constitucionalização do Princípio da Razoável Duração do Processo, as problemáticas, tanto temporal, quanto de efetividade da prestação jurisdicional, vieram à tona de forma mais densa. Essa afirmativa pode ser facilmente aferível analisando-se os dados do Justiça em Números de

\footnotetext{
* Mestrando em direito pela Universidade Federal de Sergipe e procurador da Fazenda Nacional. E-mail: joseleitesneto@hotmail.com

** Professor Associado da UFS. Especialista, Mestre e Doutor em Direito Constitucional pela UFMG, com pós-

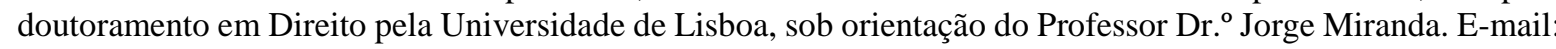
ucneto@bol.com.br
} 
$2017^{1}$, relatório do Conselho Nacional de Justiça, em que se constata ser o processo executivo e, dentro deste, as execuções fiscais, o maior gargalo do Judiciário².

O próprio relatório afirma que o novo Código de Processo Civil contribuiu na direção de um processo executivo mais equilibrado, ao criar para o credor mecanismos mais ágeis e efetivos de satisfação de seus direitos com a menor onerosidade possível para o devedor. Porém, no tocante à execução como um todo, esse documento conclui que o alto volume desse tipo de processo e alta taxa de congestionamento dificultam a efetivação da tutela jurisdicional.

Os dados são flagrantes no sentido de que é a execução o maior gargalo da prestação jurisdicional no país, sendo que, dos 80 milhões de processos pendentes de baixa no final do ano de 2016, mais da metade desses, 51,1\%, se referem à execução.

Especialmente no que tange aos executivos fiscais, a maior parte dos processos de execução é composta por esse tipo de procedimento, os quais representam 75\% do estoque. Esses processos são os principais responsáveis pela alta taxa de congestionamento do Poder Judiciário, tendo em vista que representam aproximadamente 38\% do total de casos pendentes, apresentando congestionamento de 91\% em 2016, segundo esse levantamento do Conselho Nacional de Justiça. Vide anexo I.

Os processos de execução fiscal representam, aproximadamente, $38 \%$ do total de casos pendentes em todo o país e 75\% das execuções pendentes no Poder Judiciário (Anexos II e IV). Elas apresentam, ainda, alta taxa de congestionamento, 91\%, ou seja, de cada cem processos de execução fiscal que tramitaram no ano de 2016, apenas 9 foram baixados, com a perspectiva de mais 100 novos processos no ano seguinte, o que acarreta um crescimento, de longo prazo, exponencial (vide anexo III).

Quando se compara o processo executivo ao processo de conhecimento, os dados também não são bons. Isso porque o índice de atendimento à demanda na fase de conhecimento tem sido superior a 100\% desde o ano de 2009, porém, na fase de execução esse índice tem sido inferior sempre. Isso corrobora com a constatação acima, no sentido de que os casos pendentes na execução tendem sempre a aumentar.

Várias são as causas que contribuem para esse diagnóstico. No que concerne à execução comum, não fiscal, pode-se citar: desaquecimento da economia, negócios jurídicos que

\footnotetext{
${ }^{1}$ BRASIL. Conselho Nacional de Justiça. Justiça em Números 2017: ano-base 2016. Brasília: CNJ, 2017. Disponível em: <http://www.cnj.jus.br/files/conteudo/arquivo/2017/11/100d387b0339d6d8544a29e30a3b2150.pdf>. Acesso em: 20 nov. 2017.

2 EXECUÇÕES fiscais demoram seis anos e recuperam menos de R\$ 8 mil, diz CNJ. Publicado em $1^{\circ}$ nov. 2017. Conjur. Disponível em: <https://www.conjur.com.br/2017nov-01/execucoes-fiscais-demoram-seis-anos-recuperam-mil?utm_>. Acesso em: 19 nov. 2017.
} 
lhe deram ensejo não serem garantidos por algum direito real, etc. Mas no que tange à execução fiscal, as causas são mais específicas, notadamente, e o mais importante, o fato de que há uma demora entre a constituição definitiva do crédito a ser cobrado, a localização do devedor para sua citação e, mais ainda, a localização de seu patrimônio.

Pois, entre esses atos, constituição do crédito e localização de patrimônio, os devedores efetuam diversas defesas administrativas que, não raro, demoram meses para serem julgadas em todas as instâncias, ao menos é uma prática costumeiramente vista na seara tributária $^{3}$. Ou ainda, em razão da demora narrada e do entendimento consolidado sobre a necessidade de prévia intimação para a penhora de ativos financeiros por meio do "Bacen-Jud", raramente se encontra nesse momento a garantia do crédito cobrado ${ }^{4}$. Outra causa apontada como gargalo do processo executivo fiscal é a ausência de aparelhamento das procuradorias fiscais da Fazenda Nacional, dos estados e dos municípios.

Do que se tratará esse trabalho, todavia, não são essas duas causas acima apontadas para a ineficiência do processo executivo fiscal, mas uma terceira e não menos importante, que é a subutilização dos meios atípicos de cobrança. Diz o inciso IV do art. 139 do novo Código de Processo Civil que o juiz pode "determinar todas as medidas indutivas, coercitivas, mandamentais ou sub-rogatórias necessárias para assegurar o cumprimento de ordem judicial, inclusive nas ações que tenham por objeto prestação pecuniária”. Para isso utilizar-se-á do método hipotético-dedutivo.

A hipótese aqui trabalhada será que a utilização de meios atípicos de cobrança, notadamente medidas indutivas, se adequadamente utilizadas, pode ajudar de modo decisivo à

\footnotetext{
${ }^{3}$ Com o fim de conferir maior agilidade ao julgamento das impugnações e recursos nos processos administrativos fiscais, em 16 de março de 2007 foi editada a Lei no 11.457, que assim estabeleceu: "É obrigatório que seja proferida decisão administrativa no prazo máximo de 360 (trezentos e sessenta) dias a contar do protocolo de petições, defesas ou recursos administrativos do contribuinte".

${ }^{4}$ Relacionada a essa análise micro sobre a efetividade do processo executivo fiscal, recentemente, o Tribunal de Contas da União proferiu o Acórdão de ${ }^{0}$ 1320/2017 (TC 012.659/2017-7), o qual, no que tange à análise da eficiência da cobrança da Dívida Ativa da União, consignou no item 4.1.2.10: "Recomendação: à Casa Civil da Presidência da República, em conjunto com o Ministério da Fazenda e a Advocacia Geral da União, que apresente, no prazo de 90 dias, plano de ação, contemplando um conjunto de medidas com vistas a incrementar a arrecadação de receitas referentes à Dívida Ativa da União, em consonância com o princípio da eficiência da administração pública, consubstanciado no caput do art. 37 da Constituição Federal de 1988”. E continuou: “[...] a arrecadação, considerada aqui apenas aquela decorrente da dívida ativa, chegou a R\$ 14,85 bilhões no exercício 2016. Já o percentual de realização da receita, vale dizer, a razão entre o valor arrecadado e o valor a arrecadar (estoque), ficou em $0,77 \%$. Ou seja, do estoque de créditos a recuperar inscritos em dívida ativa ao final de 2016, apenas 0,77\% foi arrecadado, evidenciando, assim, uma baixa capacidade de recuperação dos créditos regularmente inscritos em dívida ativa”. Da leitura desse documento, vê-se que o E. TCU não se aprofundou nos motivos do que chamou de "baixa arrecadação", incorrendo, "data venia", em falha metodológica, pois, dentre outras coisas, não separou de todo o montante inscrito em dívida Ativa da União os níveis de recuperabilidade dessa dívida em alto, médio e pequeno, sendo que, se se analisar a efetiva "janela de recuperação", o percentual apontado acima incrivelmente não é baixo.
} 
efetividade do processo executivo, notadamente nos casos em que não existe insolvência por parte do devedor, mas, sim, simples resistência das mais diversas formas para o pagamento. Constatada a inefetividade dos métodos executivos clássicos de sub-rogação e excussão patrimonial, resta como resposta a efetiva aplicação da cláusula aberta dos meios de cobrança para esses casos.

Apesar de dispositivo semelhante já existir desde a vigência do Código de Processo Civil anterior, os dados um tanto quanto graves referentes à taxa de congestionamento e indução do processo executivo irão necessariamente trazer à tona, mais cedo ou mais tarde, duas grandes questões; a primeira é a desjudicialização das cobranças - abordagem que foge ao propósito desse trabalho - e a segunda é a remodelagem do processo executivo, cujos métodos tradicionais de execução - as medidas típicas de sub-rogação e excussão patrimonial - já se mostram ineficientes.

Para isso faz-se necessário também romper amarras formalísticas e encarar o processo como um meio, cuja eficácia será medida em função de sua utilidade para o ordenamento jurídico e a pacificação social (BEDAQUE, 2011. p. 23). Menos interessa o conceitualismo processual do que os resultados atingidos por esse meio que se propõe a entregálos à sociedade.

Por fim, um elemento último e necessário à análise desse tema é o grau e a forma com que esses “meios executivos atípicos” serão utilizados. Como se está diante de um conceito aberto e que, necessariamente, terá que lidar com valores antagônicos envolvidos, de um lado o direito material do credor e do outro a dignidade e propriedade do devedor, a sua aplicação desembocará na ponderação de interesses e valores, logo, terá que trabalhar aqui com o conceito de proporcionalidade.

\section{2 - DA PROPORCIONALIDADE COMO PRINCÍPIO}

Em apertada síntese, a proporcionalidade foi inicialmente concebida como regra de equidade, em seguida passou a associar-se a um fundamento de controle dos atos estatais, após, serviu de substrato para o controle de legalidade de atos in concreto, e posteriormente ao controle e filtragem constitucionais. Ela representa um importante instrumento da passagem do Estado de Direito para algo mais, o Estado Constitucional de Direitos, pois, segundo Helenilson Cunha Pontes, ela permite à Constituição assumir o centro gravitacional do sistema normativo. Com isso, facilita o adequado e pormenorizado controle de validade material dos atos estatais, 
concretizando o postulado de que o direito não se esgota na lei - ato estatal que representa a vontade geral (PONTES, 2000, p. 50).

Já Karl Larenz a considera um princípio jurídico de direito material, decorrente diretamente da noção de justiça, justa medida, moderação, que se converte em fio condutor metodológico da concretização judicial da norma. E, sabendo que, na manifestação desses princípios, restará uma margem pessoal de avaliação de um lado, concebe-se a "ponderação de bens” como um processo racional que segue princípios identificáveis e, até certo ponto, comprováveis (LARENS, 2014, p. 586-587).

Por sua vez, o professor Robert Alexy sobre direitos fundamentais, na qual se dá uma excelente categorização epistemológica ao fenômeno da proporcionalidade. Diferencia regras e princípios. Diz-se inovadora, pois vai além da doutrina mais moderna que impinge essa distinção ao afirmar se tratarem os princípios de “mandamentos nucleares” ou "disposições fundamentais”, sempre com a ideia comum de que os princípios seriam as normas fundamentais do sistema (SILVA, 2003, pp. 607-630). Bem como - por lógica - supera mais ainda a doutrina tradicional que classificava os princípios apenas como mais um critério de colmatação de lacunas ${ }^{5}$.

Ainda sob a pena desse autor a proporcionalidade pode ser dividida em três regras ou máximas parciais: a adequação a meios-fins, a necessidade (mandamento de meio menos gravoso) e a proporcionalidade em sentido estrito (regra da ponderação). Sobressai-se na teoria de Alexy é que, diferentemente da maior parte da doutrina e até mesmo dos Tribunais, ele não categoriza a proporcionalidade como princípio, mas, sim, como regra instrumental para aplicação, solução de colisões e delimitação de restrições de princípios ${ }^{6}$.

Visto isso, passa-se à análise da proporcionalidade no processo civil, tendo como problemática a ponderação de valores na aplicação dos meios atípicos de cobrança e uma

\footnotetext{
${ }^{5}$ Carlos Maximiliano tece interessantes e emblemáticos comentários sobre a função tradicional dos princípios em colmatar lacunas, fazendo menção a autores do início do século XX que cunhavam aos princípios a categoria de "princípios filosóficos do direito positivo", "se acham em germe no Código", "existem em potência no Direito Natural" ou se "supõem latentes no âmago das regras explícitas". O grau de asserção dessas expressões dão uma dimensão mais nítida de como os princípios, na visão tradicional, relegados a praticamente uma categoria subjurídica. (MAXIMILIANO, Carlos. Hermenêutica e Aplicação do Direito. Rio de Janeiro: Forense, 2011. 20. ed. p. 242).

${ }^{6}$ No livro "Epílogo a la Teoria de los Derechos Fundamentales", ele esclarece que a ideia de "ponto máximo" não necessariamente indica que só haja uma resposta correta para o caso. Quanto à regra da ponderação (proporcionalidade em sentido estrito), Alexy foi mais específico e estabeleceu o significado de uma "lei de ponderação material" que estabelece que "quanto maior é o grau de não satisfação ou afetação de um princípio, maior deve ser a importância de satisfação do outro" (p. 13). Com também o que denominou de "lei de ponderação empírica”, segundo a qual "quanto mais intensa se revelar a intervenção em um dado direito fundamental, maiores hão de se revelar os fundamentos justificadores dessa intervenção. (p.38).
} 
tentativa de identificação dos princípios envolvidos e que seriam objeto de incidência da regra da proporcionalidade, quando de sua aplicação.

\section{3 - AAPLICAÇÃO DA PROPORCIONALIDADE NO PROCESSO CIVIL E OS MEIOS ATÍPICOS DE COBRANÇA}

Visto o locus da proporcionalidade na epistemologia jurídica, como regra para balizamento entre as escolhas juridicamente possíveis, pode-se adentrar de forma mais precisa em sua aplicação no processo civil. De forma geral, como o direito processual é predominantemente marcado por regras procedimentais, a aplicação da proporcionalidade é menos corriqueira do que no direito material, porém não inexistente.

Tanto isso é procedente que o novo Código de Processo Civil positivou expressamente tanto a proporcionalidade, quanto a razoabilidade, no seu artigo $8^{\circ}$, ao determinar que “Ao aplicar o ordenamento jurídico, o juiz atenderá aos fins sociais e às exigências do bem comum, resguardando e promovendo a dignidade da pessoa humana e observando a proporcionalidade, a razoabilidade, a legalidade, a publicidade e a eficiência”.

Saindo, pois de uma previsão genérica para uma aplicação efetiva e específica, notase uma regra geral na utilização da proporcionalidade, quando se confere tratamento diferenciado ao sujeitos que se encontrem em posições processuais também distintas. O caso clássico reside no tratamento diferenciado conferido à Fazenda Pública em juízo, seja protegendo determinadas situações, a exemplo da vedação do efeito material da revelia (presunção de veracidade aos fatos não impugnados) por serem os direitos versados indisponíveis ${ }^{7}$, seja concedendo-lhe institutos processuais exclusivos como a suspensão de liminar e a intervenção anômala, ou ainda várias outras regras de tratamento específicas como as prerrogativas do prazo processual em dobro para manifestação em geral ou de intimação pessoal com remessa do autos para os advogados públicos $^{8}$.

Esse discrímen traz consigo a ideia de isonomia, na medida em que a Fazenda Pública está a tutelar o interesse público, logo indisponível, pois é por todos titularizado.

\footnotetext{
${ }^{7}$ Art. 344. Se o réu não contestar a ação, será considerado revel e presumir-se-ão verdadeiras as alegações de fato formuladas pelo autor.

Art. 345. A revelia não produz o efeito mencionado no art. 344 se:

(...) II - o litígio versar sobre direitos indisponíveis;

${ }^{8}$ Art. 183. A União, os Estados, o Distrito Federal, os Municípios e suas respectivas autarquias e fundações de direito público gozarão de prazo em dobro para todas as suas manifestações processuais, cuja contagem terá início a partir da intimação pessoal.

$\S 1^{\circ} \mathrm{A}$ intimação pessoal far-se-á por carga, remessa ou meio eletrônico.
} 
Residindo, então, na proporcionalidade a medida adequada de sua aplicação. Na verdade, o dissenso doutrinário quanto ao tratamento diferenciado da Fazenda Pública está na medida qualitativa das prerrogativas, e não em sua existência.

Nas palavras de Leonardo Carneiro da Cunha, as “vantagens” que o processo confere ao Poder Público revestem-se de prerrogativas, pois conferem tratamento razoável em atender de forma efetiva ao princípio da igualdade, no sentido aristotélico de tratar os iguais desigualmente. E continua o autor ao afirmar que essas prerrogativas são justificadas pelo excesso de carga de trabalho, pelas dificuldades estruturais da Advocacia Pública e pela burocracia inerente à sua atividade, o que dificulta o acesso aos fatos, elementos e dados da causa (CUNHA, 2016. p. 33).

Decerto a ideia inerente a esse tratamento diferenciado da Fazenda Pública no processo civil é o Princípio da Isonomia, mas notadamente balizado pela regra da proporcionalidade. Destarte, adentrando um pouco mais na análise da proporcionalidade nesse ramo do direito, passa-se a analisar um dos casos emblemáticos sobre a sua aplicação no processo civil.

Trata-se do tema julgado na Ação Declaratória de Constitucionalidade $n^{\circ} 4^{9}$ pelo Supremo Tribunal Federal. A mesma visou dirimir crise de certeza que se estabelecia em torno do art. $1^{\circ}$ da lei 9.494, de 10 de setembro de 1997, que assim estabelece: “Aplica-se à tutela antecipada prevista nos arts. 273 e 461 do Código de Processo Civil o disposto nos arts. $5^{\circ}$ e seu parágrafo único e $7^{\circ}$ da Lei $n^{\circ} 4.348$, de 26 de junho de $1964^{10}$, no art. $1^{\circ}$ e seu $\S 4^{\circ}$ da Lei

\footnotetext{
${ }^{9}$ BRASIL. Supremo Tribunal Federal. ADC 4, relator: Min. Sydney Sanches, relator p/ Acórdão: Min. Celso de Mello, Tribunal Pleno, julgado em 01/10/2008, Dje-213. Divulg 29-10-2014. Public 30-10-2014. Ement Vol-02754-01 PP00001. Ementa: Ação declaratória de constitucionalidade - processo objetivo de controle normativo abstrato - natureza dúplice desse instrumento de fiscalização concentrada de constitucionalidade - possibilidade jurídico-processual de concessão de medida cautelar em sede de ação declaratória de constitucionalidade - inerência do poder geral de cautela em relação à atividade jurisdicional - caráter instrumental do provimento cautelar cuja função básica consiste em conferir utilidade e assegurar efetividade ao julgamento final a ser ulteriormente proferido no processo de controle normativo abstrato - importância do controle jurisdicional da razoabilidade das leis restritivas do poder cautelar deferido aos juízes e tribunais - inocorrência de qualquer ofensa, por parte da Lei $n^{\circ} 9.494 / 97\left(\operatorname{art.~}^{\circ}\right.$ ), aos postulados da proporcionalidade e da razoabilidade - legitimidade das restrições estabelecidas em referida norma legal e justificadas por razões de interesse público - ausência de vulneração à plenitude da jurisdição e à cláusula de proteção judicial efetiva - garantia de pleno acesso à jurisdição do estado não comprometida pela cláusula restritiva inscrita no preceito legal disciplinador da tutela antecipatória em processos contra a fazenda pública - outorga de definitividade ao provimento cautelar que se deferiu, liminarmente, na presente causa - ação declaratória de constitucionalidade julgada procedente para confirmar, com efeito vinculante e eficácia geral e "ex tunc", a inteira validade jurídico-constitucional do art. $1^{\circ}$ da Lei 9.494, de 10/09/1997, que "disciplina a aplicação da tutela antecipada contra a fazenda pública”.

${ }^{10}$ Antes de serem revogados pela lei $\mathrm{n}^{\circ} 12.016$, de 2009, esses dispositivos assim estabeleciam: “Art. $5^{\circ}$ Não será concedida a medida liminar de mandados de segurança impetrados visando à reclassificação ou equiparação de servidores públicos, ou à concessão de aumento ou extensão de vantagens

Parágrafo único. Os mandados de segurança a que se refere este artigo serão executados depois de transitada em julgado a respectiva sentença. (...)

Art. $7^{\circ} \mathrm{O}$ recurso voluntário ou 'ex officio', interposto de decisão concessiva de mandado de segurança que importe
} 
$\mathrm{n}^{\mathrm{o}} 5.021$, de 9 de junho de $1966^{11}$, e nos arts. $1^{\circ}$, $3^{\circ}$ e $4^{\circ}$ da Lei $n^{\circ} 8.437$, de 30 de junho de 1992”12. Em linhas regais esses dispositivos proibiam ou proíbem provimentos cautelares ou antecipatórios em face do Poder Público.

Rememore-se que, à época das leis multirreferidas, o instituto da antecipação de tutela ainda não existia no ordenamento jurídico, somente o sendo concebido pela lei 8.952, de 13 de dezembro de 1994. Ou seja, conjugado com o $\S 3^{\circ}$ do art. $1^{\circ}$ da Lei 8.437, de 30 de junho de 1992, que veda a concessão de "medida liminar que esgote, no todo ou em qualquer parte, o objeto da ação”, esse dispositivo da Lei 9.494/97 fechou o sistema processual de garantias à Fazenda Pública contra qualquer medida antecipatória que implique saída de recursos públicos que, em caso de reversão do provimento, muito dificilmente seriam recuperados.

Na referida ADC, é possível extrair dois conteúdos principais: o primeiro é que o poder cautelar, no sentido de se assegurar resultado ou prova úteis ao processo, é inerente ao próprio poder jurisdicional, exatamente por lhe ser instrumental. Logo, somente pode ser restringido se houver motivo razoável. Já o segundo conteúdo, objeto desse trabalho, afirma que as restrições à tutela cautelar trazidas pela Lei n. 9.494/97 não vulneram a plenitude da jurisdição, uma vez que elas foram estabelecidas de modo razoável e proporcional por razões de interesse público ${ }^{13}$.

Após essa decisão em controle concentrado, todavia, sobrevieram várias decisões inusitadamente relativizando a ponderação efetuada pelo STF sobre o tema. Tal ocorre no sentido de que a constitucionalidade do dispositivo que veda as referidas tutelas de urgência, a despeito de

outorga ou adição de vencimento ou ainda reclassificação funcional, terá efeito suspensivo”.

${ }^{11}$ Dispositivos também revogados pela lei 12.016, de 2009: "Art. $1^{\circ} \mathrm{O}$ pagamento de vencimentos e vantagens pecuniárias asseguradas, em sentença concessiva de mandado de segurança, a servidor público federal, da administração direta ou autárquica, e a servidor público estadual e municipal, somente será efetuado relativamente às prestações que se vencerem a contar da data do ajuizamento da inicial. (...)

$\S 4^{\circ}$ Não se concederá medida liminar para efeito de pagamento de vencimentos e vantagens pecuniárias".

12 “Art. $1^{\circ}$ Não será cabível medida liminar contra atos do Poder Público, no procedimento cautelar ou em quaisquer outras ações de natureza cautelar ou preventiva, toda vez que providência semelhante não puder ser concedida em ações de mandado de segurança, em virtude de vedação legal. (...)

Art. $3^{\circ} \mathrm{O}$ recurso voluntário ou ex officio, interposto contra sentença em processo cautelar, proferida contra pessoa jurídica de direito público ou seus agentes, que importe em outorga ou adição de vencimentos ou de reclassificação funcional, terá efeito suspensivo.

Art. $4^{\circ}$ Compete ao presidente do tribunal, ao qual couber o conhecimento do respectivo recurso, suspender, em despacho fundamentado, a execução da liminar nas ações movidas contra o Poder Público ou seus agentes, a requerimento do Ministério Público ou da pessoa jurídica de direito público interessada, em caso de manifesto interesse público ou de flagrante ilegitimidade, e para evitar grave lesão à ordem, à saúde, à segurança e à economia públicas”.

${ }^{13}$ BRASIL. Superior Tribunal de Justiça. REsp 1036968/DF, relator: Ministro Teori Albino Zavascki, data de julgamento: 13/05/2008, Primeira Turma, DJe 28/05/2008. Ementa: Processual civil. FGTS. Obrigação de fazer. Astreintes. Art. 461, do CPC. "Astreites". Art. 461, do CPC. Possibilidade. Revisão do "quantum" estipulado. Matéria Fática. Súmula 7/STJ. 
ser constitucional, não impediria, no caso concreto, de se afastar a vedação quando ocorresse colisão entre os valores envolvidos, com a irreversibilidade da medida em ambos os lados, tanto da concessão da tutela, quanto da sua denegação. Ou seja, haveria, no caso concreto, de se ponderar entre os valores e princípios atinentes a cada uma dessas opções ${ }^{14} 1516$.

Deslocando-se do aspecto geral da proporcionalidade no processo civil para o aspecto específico, tem-se uma série de institutos processuais em que, quando de sua aplicação, essa regra da proporcionalidade encontra abrigo. O mais clássico deles é o controle dos atos executivos em face do devedor pelo Princípio da Menor Onerosidade da execução. Cândido Rangel Dinamarco, ao comentar esse princípio, assevera que a execução teve que deixar de ter um caráter punitivo, de infâmia, passando a obedecer limites, chamados por ele de políticos, com o fim de preservar a dignidade da pessoa humana, do patrimônio e, em geral, dos direitos da personalidade (DINAMARCO, 2013, pp. 295-296).

É nesse contexto de ponderação entre os Princípios da Menor Onerosidade da execução - que ao fim trata-se da aplicação da Dignidade da Pessoa Humana ao devedor - de um lado e a necessidade de sua efetividade do outro, que se insere a relação entre os meios atípicos de cobrança e a regra da proporcionalidade.

Como a finalidade precípua do processo executivo ou da fase de cumprimento de sentença consiste basicamente na realização de atos de sub-rogação, indução ou coação do devedor para o adimplemento da dívida e, como a execução por quantia certa - da qual a execução fiscal é um subtipo - consiste basicamente na realização de atos materiais tendentes a

\footnotetext{
${ }^{14}$ BRASIL. Tribunal Regional Federal da $5^{\mathrm{a}}$ região. TRF-5. REEX: 827920124058101, relator: Desembargador Federal Rogério Fialho Moreira, data de julgamento: 03/12/2013, Quarta Turma, data de publicação: 05/12/2013. Ementa: Administrativo. fornecimento de medicamento. Temodal (temozolamida). Agravo retido e apelações. Honorários advocatícios. Apreciação equitativa. Direito à saúde. Responsabilidade solidária dos entes da federação. Legitimidade ad causam do estado do Ceará e da União. Pressupostos para a concessão da tutela antecipada. Existência. Irreversibilidade do provimento. Ponderação. Interesse de agir. Existência. Ausência de violação aos princípios da separação dos poderes e reserva do possível.

${ }^{15}$ BRASIL. Tribunal Regional Federal da 4 a região. TRF-4. AG: 2009.04.00.016813-3/PR, relatora: Desembargadora Federal Silvia Maria Gonçalves Goraieb, data de julgamento: 13/10/2009, Terceira Turma, D.E. 28/10/2009. Ementa: Agravo de instrumento. Administrativo. Constitucional. Ação civil pública. Legitimidade ativa do Ministério Público Federal. Fornecimento de medicamentos. Direito à saúde. Eis trecho emblemático do voto condutor: "A irreversibilidade dos efeitos da medida, prevista no $\S 2^{\circ}$ do art. 273 do CPC, não impede para a concessão do provimento antecipatório, pois o princípio da proporcionalidade deve inspirar a prestação jurisdicional, devendo o julgador precatar aquele interesse de maior valor".

${ }^{16}$ BRASIL. Tribunal Regional Federal da $4^{\mathrm{a}}$ região. TRF-4. AG: 2005.04.01.011695-1/RS, relatora: Vânia Hack de Almeida, data de julgamento: 26/09/2005, Terceira Turma, data de publicação: DJ 13/10/2005, página: 576. Ementa: Militar. Acidente ocorrido no período de prestação de serviço militar. Tratamento médico. Manutenção como adido. Eis trecho do voto condutor: “(...) A irreversibilidade dos efeitos da medida a que se refere o $\$ 2^{\circ}$ do art. 273 do CPC não se pode erigir em impedimento inafastável ao deferimento de provimento antecipatório em casos como o dos autos. O princípio da proporcionalidade deve inspirar a prestação jurisdicional, de jeito que, na colisão de interesses, deve o julgador precatar aquele de maior valor, o qual, no caso, reputa-se ser o pertencente ao agravado".
} 
retirar o patrimônio do devedor, o processo civil brasileiro sempre carregou a marca da tipicidade nos meios de cobrança.

A razão dessa cultura detém uma explicação relativamente fácil, pois logo ao lado do direito à liberdade, o direito de propriedade carrega uma elevada densidade valorativa, sendo, pois, da alçada do direito processual controlar esses atos estatais que atingem o patrimônio do particular, sempre sob o manto do devido processo legal.

Nesse ponto reside a problemática sobre a qual se discorre, que é analisar e fomentar a aplicação dos meios atípicos de cobrança, pois o diagnóstico da inefetividade do processo executivo é evidente, sendo que o excesso de procedimentalização dos meios típicos de cobrança e demora em sua realização conferem aos credores tempo e previsibilidade de atos suficientes para dilapidarem seu patrimônio.

De fato, desde do Código de Processo Civil anterior havia previsão dos meios atípicos de cobrança, mas sua aplicação sempre foi assaz tímida, senão inexistente. Essa resistência ressoava inclusive na jurisprudência do STJ, no sentido de apenas considerar possível a cominação de multa nas execuções de obrigação de dar e fazer/não fazer ${ }^{1718}$. O fundamento para isso geralmente perpassava pela diferença entre os procedimentos e incompatibilidade do antigo art. 475-J com relação ao procedimento dos antigos arts. 461 e 461-A. Ademais, argumentava ser ilógica a possibilidade de arbitrar multa em execução por quantia certa para quem já não pagava o próprio débito principal, bem como, após a previsão da multa de $10 \%$ no art. 475-J, o fato de a própria lei agora já cominar um valor fixo e de incidência única de multa.

Independentemente do motivo, ao lado da constatação da baixa efetividade do processo executivo por quantia certa, também se afere a obediência marcadamente rígida aos meios típicos de execução, especificamente, a expropriação. Cite-se: tentativa de penhora “on line”, restrição de veículos no sistema Renajud, intermináveis ofícios a cartórios de registro de imóveis em busca de patrimônio dos devedores, etc. Já nos casos de execução de título extrajudicial, em que não houve um processo de conhecimento prévio, esse dilema é ainda mais agravado, pois o desgaste processual se inicia já para se citar o executado, que, via de regra não é localizado com facilidade.

\footnotetext{
${ }^{17}$ BRASIL. Superior Tribunal de Justiça. REsp 1036968/DF, relator: Ministro Teori Albino Zavascki, data de julgamento: 13/05/2008, Primeira Turma, DJe 28/05/2008. Ementa: Processual civil. FGTS. Obrigação de fazer. Astreintes. Art. 461, do CPC.

${ }^{18}$ BRASIL. Supremo Tribunal Federal. ADC 4, relator: Min. Sydney Sanches, relator p/ Acórdão: Min. Celso de Mello, Tribunal Pleno, julgado em 01/10/2008, Dje-213. Divulg 29-10-2014. Public 30-10-2014. Ement Vol02754-01 PP-00001. Ementa: Ação Declaratória de Constitucionalidade.
} 
Decerto, não se quer imputar à tipicidade dos meios de execução todos os problemas de inefetividade dessa fase do processo. Isso porque o chamado "Princípio da Tipicidade dos Meios Executivos” cumpre o valioso papel de restringir o poder jurisdicional e minimizar os riscos de arbítrio, na medida em que o constrangimento patrimonial apenas seria exercido nos limites dos meios expressamente tipificados em lei (MARINONI, 2016, p. 830). Todavia os números constatados na introdução desse trabalho demonstram que há algo de errado no processo executivo brasileiro.

Ademais, a tentativa de se modificar a cultura do legalismo estrito - diz-se estrito, pois a atipicidade dos meios de cobrança também é prevista em lei - não é tão recente. Desde a edição da Lei ${ }^{\circ}$ 8.952, de 13 de dezembro de 1994, que modificou o art. 461 do antigo Código de Processo Civil, havia expressa possibilidade de utilização de medidas executivas outras nas execuções de fazer e não fazer.

O mesmo dispões que "Para a efetivação da tutela específica ou a obtenção do resultado prático equivalente, poderá o juiz, de ofício ou a requerimento, determinar as medidas necessárias, tais como (...)”. De fato, a tímida redação do dispositivo que trazia essa possibilidade, uma vez o termo “tais como” indicava se seguir de uma relação não exaustiva de meios executivos.

No mesmo sentido de que essa atipicidade executiva não configura novidade do novo Código de Processo Civil, Daniel A. Assumpção Neves já apontava a norma desse dispositivo desde o código de processo anterior, mas que, devido a sua presença topográfica no artigo referente à execução de fazer e não fazer, contribuía para sua não aplicação à execução por quantia certa (NEVES, p. 231).

Entrementes, o que contribui para a manutenção da "cultura da tipicidade dos meios executivos”, além do apego demasiado ao formalismo processual, pode residir num virtual “sub-regramento" ou "subnormatização” dos meios atípicos de cobrança, pois até 1994 o instituto inexistia com previsão expressa. Não muito diferente também é o novo regramento erigido pelo atual CPC, já que se dedicou aos meios atípicos de cobrança em apenas 3 ocasiões (inciso IV do art. 139, art. 526 e art. 538), enquanto que a execução por quantia certa, na modalidade sub-rogatória, continua sendo regulada minudentemente por oitenta e oito dispositivos legais (arts. 523-525 e 824-909 e ss).

Em passagem elucidativa, Luiz Guilherme Marinoni afirma o equívoco de se entender que a tutela executiva expropriatória estaria atrelada ao direito material pecuniário declarado no título executivo, enquanto que a tutela específica estaria atrelada aos títulos 
executivos não pecuniários (MARINONI, 2016, p. 832). Nesse sentido, aponta a importância do inciso IV do art. 139 do novo CPC como portador de “cláusula de encerramento de sistema”, conclamando esse dispositivo para presidir todo o sistema de efetivação das decisões judiciais. Tendo, pois, o sistema brasileiro previsto formas executivas abertas e atípicas para todos os tipos de prestações (MARINONI, 2016, p. 833).

Diante dessa verdadeira "síndrome de inefetividade” (tomando o termo emprestado dos estudos de jurisdição constitucional, quando dispõe sobre a normas constitucionais de eficácia limitada pendentes de regulamentação) do processo executivo, na modalidade por quantia certa, a doutrina começa a dar os primeiros sinais de maior atenção para a importância da norma existente no referido dispositivo. Vide os Enunciados 12 e 369 do Fórum Permanente de Processualistas Civis, após a vigência do novo CPC:

Enunciado 12: (arts. 139, IV, 523, 536 e 771). A aplicação das medidas atípicas subrogatórias e coercitivas é cabível em qualquer obrigação no cumprimento de sentença ou execução de título executivo extrajudicial. Essas medidas, contudo, serão aplicadas de forma subsidiária às medidas tipificadas, com observação do contraditório, ainda que diferido, e por meio de decisão à luz do art. 489, § $1^{\circ}$, I e II. (Grupo: Execução). Enunciado 396: (art. 139, IV; art. $8^{\circ}$ ). As medidas do inciso IV do art. 139 podem ser determinadas de ofício, observado o art. $8^{\circ}$. (Grupo: Poderes do juiz). ${ }^{19}$

Bem como o Enunciado 48 da Escola Nacional de Formação de Magistrados:

O art. 139, IV, do CPC/2015 traduz um poder geral de efetivação, permitindo a aplicação de medidas atípicas para garantir o cumprimento de qualquer ordem judicial, inclusive no âmbito do cumprimento de sentença e no processo de execução baseado em títulos extrajudiciais”20.

Novamente nas lições do Dinamarco, em que pese ter escrito anteriormente ao novo CPC, já se nota uma verdadeira convocação à efetividade da tutela jurisdicional em busca de um equilíbrio ${ }^{21}$ entre o interesse do credor e a existência de um mínimo patrimonial do devedor, porém, sem se conferir a esse o direito de resistir incontrolavelmente ao exercício da jurisdição

${ }^{19}$ FPPC. Fórum Permanente de Processualistas Civis. Enunciados do Fórum Permanente de Processualistas Civis. São Paulo, 18, 19 e 20 de março de 2016. Disponível em: <http://www.cpcnovo.com.br/wpcontent/uploads/2016/06/FPPC-Carta-de-Sa\%CC\%83o-Paulo.pdf>. Acesso em: 20 nov. 2017.

20 Escola Nacional de Formação de Magistrados. Disponível em: http://www.enfam.jus.br/wpcontent/uploads/2015/09/ENUNCIADOS-VERS\%C3\%83O-DEFINITIVA-.pdf. Acesso em: 20 nov. 2017.

${ }^{21} \mathrm{O}$ autor, nesse ponto, ainda é mais emblemático ao falar em "equilíbrio”, no sentido de nem se crucificar o devedor que não pode pagar e nem relaxar o sistema e deixá-lo nas mãos de caloteiros e chicanistas que se escondem e protegem sob o manto de regras e sub-regras processuais e garantias constitucionais manipuladas de modo a favorecê-los em sua obstinação a não adimplir. (...) O zelo pela vida das empresas, que justifica uma série de cautelas na penhora de bens de propriedades destas, não é motivo para impedir de modo absoluto o equilíbrio do sistema executivo, a dano do credor e em desprestígio das decisões judiciárias. (...) Não havendo outro meio razoável e ameno para satisfazer o credor, que se penhore toda a empresa, ou seu estabelecimento mesmo, ou mesmo se transfira a terceiro (mediante o procedimento de expropriação, inerente à execução por quantia certa) as próprias atividades da empresa devedora. Tudo, menos deixar o credor insatisfeito. 
(DINAMARCO, 2013, p. 296). Ele arremata com incisão: no sentido de que se se constata uma execução completamente incapaz de produzir os resultados desejados, é preciso que os juízes se disponham a empregar as ferramentas que a lei coloca à disposição sem ignorância (no sentido de desconhecimento) ou sem medo de impor suas decisões (DINAMARCO, 2013, p. 300).

Não por outro motivo, já começam a surgir as primeiras decisões com aplicação efetiva e inovadora de meios atípicos de cobrança, como por exemplo a suspensão de carteira nacional de habilitação e do passaporte de devedores a fim de induzi-los ao pagamento da dívida MENGARDO, Bárbara. Tribunais começam a suspender passaporte de devedor (MENGARDO, 2017) ${ }^{22}$. Nelas começa-se a notar, ainda que implicitamente, uma invocação à proporcionalidade, já que indubitavelmente há uma relativização dos valores envolvidos, notadamente um embaraço (não necessariamente cerceamento) ao direito de ir e vir dos devedores de um lado e, de outro, o direito dos credores em receberem seus créditos.

Na linha do asseverado acima, seria cientificamente impróprio imputar o diagnóstico de inefetividade do processo executivo somente à subutilização dos meios atípicos de cobrança. Porém, das várias alternativas que se apresentam para conferir efetividade às execuções judiciais, a adoção desses meios atípicos se mostram a mais economicamente viável e socialmente adequada, a única barreira seria a superação de uma “cultura jurídica” dos meios executivos típicos.

Diz-se economicamente viável, pois para se aumentar a eficiência das execuções tais como se apresentam hoje, mas mantendo as mesmas formas típicas de cobrança, apenas seria possível aumentando o gasto público com a máquina do Judiciário, contratando-se mais juízes e auxiliares da justiça, etc. Algo que é deveras caro e cujo o preço a própria sociedade tenderá a questionar ${ }^{23}$.

\footnotetext{
${ }^{22}$ Em Recente julgamento sobre a mesma matéria, assim decidiu o TJ/MG: PARA que réu pague dívida, juíza suspende CNH e confisca passaporte. Consultor Jurídico. Publicado em 7 set. 2016. Disponível em: $<$ https://www.conjur.com.br/2016-set-07/reu-pague-divida-juiza-suspende-cnh-confisca-passaporte>. Acesso em: 03 nov. 2017.

${ }^{23}$ Dados sobre o gasto do poder judiciário. "No exercício do poder de direção do processo, o magistrado não deve descuidar dos princípios e garantias estampados na Carta Magna, além de lhe competir a observância da proporcionalidade, razoabilidade, legalidade, publicidade e eficiência na aplicação do ordenamento jurídico, nos termos do art. $8^{\circ}$ do CPC. Deve ser desconstituída a ordem de suspensão da Carteira Nacional de Habilitação $(\mathrm{CNH})$ quando ela se mostrar desproporcional, irrazoável e ineficiente no caso concreto, sobretudo quando impedir a parte executada-devedora de exercer livremente a sua profissão (caminhoneiro) e, portanto, auferir renda, prejudicando o próprio sustento e de sua família, bem como o pagamento da dívida exequenda” (TJMG - Agravo de Instrumento-Cv 1.0177.07.007356-0/001, Relator(a): Des.(a) Mota e Silva , $18^{\mathrm{a}}$ CÂMARA CÍVEL, julgamento em 12/09/2017, publicação da súmula em 15/09/2017). Inteiro teor disponível em: http://www5.tjmg.jus.br/jurisprudencia/pesquisaPalavrasEspelhoAcordao.do?\&numeroRegistro=5\&totalLinhas= 40\&paginaNumero=5\&linhasPorPagina=1\&palavras=139,\%20IV\&pesquisarPor=ementa\&pesquisaTesauro=tru
} 
Quanto à adequação social dos aludidos meios atípicos de cobrança, é um tema que tem afinidade com os "escopos social e político" da jurisdição, sob a doutrina de Dinamarco ${ }^{24}$. Tal adequação queda vislumbrável, na medida em que a jurisdição e a reafirmação da lei que foi infringida (não pagamento de um crédito) funcionaria com efeito dissuasório perante o próprio devedor futuramente e perante outros devedores. Analogamente, funcionaria com caráter preventivo geral e específico da pena, no direito penal.

Nesse toar, a efetividade do processo, em especial do processo executivo, deve ser encarada como seu próprio fim. O meio para isso reside em utilizar esse processo como instrumento a serviço do direito material, de forma imediata, e da própria sociedade de forma mediata. Dentro desse tensionamento de valores e concorrência de princípios envolvidos, o critério de solução deve ser a regra da proporcionalidade, na forma acima discorrida.

Nessa mesma linha de conceber o processo como instrumento a serviço do direito material, se o direito processual não se adequar em razão do direito material, ter-se-á um instrumento absolutamente ineficaz. Nas palavras de Bedaque, é necessário ter ciência que instrumentalidade não se compatibiliza com neutralidade ou indiferença, quanto às necessidades encontradas no plano material (BEDAQUE, 2011, p. 70). Nesse mesmo sentido, Dinamarco invoca o que chama de "retomada” da dogmática processual, só que, agora, com o "espírito esclarecido” pelos objetivos a se alcançar (DINAMARCO, p. 13).

Na visão desse professor, a legitimação do processo perpassa pela compatibilidade do sistema processual com a realidade axiológica da sociedade. Tal qual edificado nas leis, assimilado pela doutrina e aplicado pelos tribunais (DINAMARCO, pp 164-165). Nem se faz necessário um maior esforço de compreensão para se poder afirmar que os credores insatisfeitos tendem a perder a fé no sistema processual e, na mesma medida, os demais potenciais devedores tendem a confiar na ausência de maiores consequências jurídicas e sociais do seu inadimplemento.

\section{4 - CONCLUSÕES}

O escopo desse trabalho foi trazer a lume uma discussão que já se mostra incipiente na doutrina desde a edição do novo Código de Processo Civil, sobre aplicação dos meios executórios atípicos no processo de execução. A razão disso é imperiosa, uma vez que a

e\&orderByData=1\&referenciaLegislativa=Clique\%20na\%20lupa\%20para\%20pesquisar\%20as\%20refer\%EAnci as\%20cadastradas...\&pesquisaPalavras=Pesquisar\&.

${ }^{24} \mathrm{~A}$ instrumentalidade do processo. 
execução tem se mostrado o verdadeiro gargalo de efetividade da prestação jurisdicional no Brasil. Os dados a respeito dessa conclusão são incontestes, vide o último levantamento do CNJ no chamado “Justiça em Números 2017”.

Essa nova Lei Adjetiva não inovou no ordenamento jurídico, quando previu no inciso IV do art. 139 expressamente os meios atípicos de cobrança. Isso porque o Código de Processo Civil anterior já detinha previsão semelhante no seu art. 461 para a efetivação das chamadas tutelas específicas. Porém, o novo CPC, ao colocá-lo num capítulo "Dos Poderes, dos Deveres e da Responsabilidade do Juiz”, inegavelmente conotou um significado mais expressivo a essa norma, já que seu alcance chega a todo e qualquer provimento judicial, não mais se restringido a uma determinada fase do processo e em uma tutela chamada específica.

Havendo, a partir de agora, previsão normativa de amplo alcance, não restará outro empecilho à utilização dos meios atípicos de cobrança senão a cultura jurídica do inadimplemento. Algo odioso e que corrói a legitimidade do processo e da própria jurisdição poder estatal por excelência - podendo acarretar efeitos deletérios ao tecido social, como a crença generalizada na não realização da justiça e agravamento ainda maior da cultura do inadimplemento. Não por outro motivo, foi visto anteriormente que o novo CPC em seu art. $8^{\circ}$ determinou ao juiz a observância dos “fins sociais e as exigências do bem comum”.

Como cláusula aberta e de enceramento do sistema, o inciso IV do art. 139 do novo CPC, que positiva os meios atípicos de cobrança, coloca ao alvedrio dos intérpretes e aplicadores da lei a criação e inovação nas formas executivas. Os exemplos começam a surgir, como a suspensão de carteira nacional de habitação ou a retenção de passaporte dos devedores. Outros poderiam vir a ser aplicados, como corte no fornecimento de energia elétrica, cartão de crédito, suspensão de matrícula do devedor de um ente federado, quando estudar em instituição de ensino pública etc. Nesse aspecto, não existiria limite à criatividade, a única baliza seria a proporcionalidade no caso concreto.

O processo ou fase de execução, ao se utilizar dos meios atípicos de cobrança, inegavelmente chegará a um ponto de inflexão. Terá que optar entre algum valor de defesa do executado - pressupondo que as diligências patrimoniais comuns foram infrutíferas, pois se não o fossem, seria esse patrimônio indisponibilizado ou penhorado -, mas valores atinentes de alguma forma à sua dignidade (como o fornecimento de energia ou a possibilidade de dirigir veículo automotor) de um lado e do outro o direito do credor, que só tem o judiciário a recorrer.

Eis o locus típico para aplicação da regra da proporcionalidade, tanto da "lei da ponderação material”, quanto da “lei da ponderação empírica”, na doutrina de Alexy. A primeira 
seria ferramenta útil à procedimentalização da regra da proporcionalidade, mais precisamente da sub-regra da ponderação, quando avaliaria o grau de importância dos valores envolvidos. Sendo mais específico, o grau de inadimplência - quantidade da(s) dívida(s) - e a comprovação inequívoca que o inadimplemento do devedor se dá a despeito de sua capacidade de pagamento, sendo essa aferível no contexto de indícios ou de demonstrações exteriores de padrão de riqueza.

Já a "lei da ponderação empírica” viria a lume para verificação do grau de comprometimento da legitimidade do sistema judiciário, a fim de se aferir os fundamentos justificadores da intervenção nos direitos fundamentais dos devedores. Quanto maior o índice de frustração de execuções em uma dada comunidade, maior a possibilidade de perda de legitimidade da jurisdição e de frustração dos credores; com isso, maiores valores deverá ter o direito de cobrança dos credores, quando da regra da ponderação relativizar seus direitos.

\section{7 - REFERÊNCIAS}

ALEXY, Robert. Epílogo a la Teoria de los Derechos Fundamentales. Traduccion Carlos Bernal Pulido. Revista Española de Derecho Constitucional, ano 22, nº 66, 2002.

ALEXY, Robert. Teoria dos Direitos Fundamentais. Tradução Virgílio Afonso da Silva. São Paulo: Malheiros, 2008.

BEDAQUE, José Roberto dos Santos. Direito e Processo. 6. ed. São Paulo: Malheiros, 2011.

BOBBIO, Norberto. Teoria do Ordenamento Jurídico. 6. ed. Tradução Maria Celeste C. J. Santos. Brasília: Editora Universidade de Brasília.

BONAVIDES, Paulo. Curso de Direito Constitucional. São Paulo: Malheiros, 1996.

BRASIL. Conselho Nacional de Justiça. Justiça em Números 2017: ano-base 2016. Brasília: CNJ, 2017.2 Disponível em: <http://www.cnj.jus.br/files/conteudo/arquivo/2017/11/100d387b0339d6d8544a29e30a3b215 0.pdf>. Acesso em: 20 nov. 2017.

DINAMARCO, Cândido Rangel. A nova era do processo civil. 4. ed. 2013. São Paulo. Malheiros.

ESCOLA NACIONAL DE FORMAÇÃO DE MAGISTRADOS. Disponível em: http://www.enfam.jus.br/wp-content/uploads/2015/09/ENUNCIADOS-VERS\%C3\%83ODEFINITIVA-.pdf. Acesso em: 20 nov. 2017.

EXECUÇÕES fiscais demoram seis anos e recuperam menos de R\$ 8 mil, diz CNJ. Publicado em $1^{\circ}$ nov. 2017. Conjur. Disponível em: <https://www.conjur.com.br/2017- 
nov-01/execucoes-fiscais-demoram-seis-anos-recuperam-mil?utm_>. Acesso em: 19 nov. 2017.

FPPC. Fórum Permanente de Processualistas Civis. Enunciados do Fórum Permanente de Processualistas Civis. São Paulo, 18, 19 e 20 de março de 2016. Disponível em: $<$ http://www.cpcnovo.com.br/wp-content/uploads/2016/06/FPPC-Carta-de-Sa\%CC\%83oPaulo.pdf>. Acesso em: 20 nov. 2017.

FRANÇA. Declaração dos Direitos do Homem e do Cidadão de 1789. Disponível em: $<$ http://pfdc.pgr.mpf.mp.br/atuacao-e-conteudos-de-apoio/legislacao/direitoshumanos/declar_dir_homem_cidadao.pdf>. Acesso em 01 ago 2017. Para a versão em francês, conferir Conseil Constitutionnel. Disponível em: <http://www.conseilconstitutionnel.fr/conseil-constitutionnel/francais/la-constitution/la-constitution-du-4-octobre1958/declaration-des-droits-de-l-homme-et-du-citoyen-de-1789.5076.html>. Acesso em: $1^{\circ}$ ago. 2017.

GUERRA FILHO, Willis Santiago. A interpretação Especificamente Constitucional. In: CRETTON, Ricardo Aziz. Os Princípios da Proporcionalidade e da Razoabilidade e sua Aplicação no Direito Tributário. Rio de Janeiro: Lumen Juris, 2001.

INGLATERRA. Magna Carta, outorgada por João-Sem-Terra em 15 de Junho de 1215. Versão em português: Consciência e vontade, publicado em 9 ago 2009. Disponível em: $<$ https://georgelins.com/2009/08/09/a-magna-charta-de-joao-sem-terra-1215-a-peticao-dedireitos-1628-e-o-devido-processo-legal/> . Acesso em 01 ago 2017. Para acesso ao texto em inglês, conferir Treasures in full. Disponível em: <http://www.bl.uk/treasures/magnacarta/translation/mc_trans.html>. Acesso em: $1^{\mathrm{o}}$ ago. 2017.

LARENS, Karl. Metodologia da Ciência do Direito. Tradução José Lamengo. 7. ed. Lisboa: Fundação Calouste Gulbenkian, 2014.

MARINONI, Luiz Guilherme; ARENHART, Sergio Cruz, MITIDIERO, Daniel. Novo Curso de Processo Civil: tutela dos direitos mediante procedimento comum, Volume II. 2. ed. Ver. Atuali. Ampli. São Paulo: Editora Revista dos Tribunais, 2016.

MAXIMILIANO, Carlos. Hermenêutica e Aplicação do Direito. 20. ed. Rio de Janeiro: Forense, 2011. 
MENGARDO, Bárbara. Tribunais começam a suspender passaporte de devedor. Jota. Publicado em 24 abr. 2017. Disponível em: <https://jota.info/justica/tribunais-comecam-asuspender-passaporte-de-devedor-24042017> . Acesso em: 03 nov. 2017.

NEVES, Daniel Amorim Assumpção. Novo Código de Processo Civil Comentado. Salvador: Jus Podvim.

PARA que réu pague dívida, juíza suspende $\mathrm{CNH}$ e confisca passaporte. Consultor Jurídico. Publicado em 7 set. 2016. Disponível em: <https://www.conjur.com.br/2016-set07/reu-pague-divida-juiza-suspende-cnh-confisca-passaporte>. Acesso em: 03 nov. 2017.

PHILIPPE, Xavier. Le Contrôle de Proporcionalité dans les Jurisprudences Constituicionelle et Administrative Françaises. In: CRETTON, Ricardo Aziz. Os Princípios da Proporcionalidade e da Razoabilidade e sua Aplicação no Direito Tributário. Rio de Janeiro: Lumen Juris, 2001.

PONTES, Helenilson Cunha. O Princípio da Proporcionalidade e o Direito Tributário. São Paulo: Dialética, 2000.

SILVA, Virgílio Afonso da. Princípios e regras: mitos e equívocos acerca de uma distinção. Revista Latino-Americana de Estudos Constitucionais, nº 1, 2003, pp. 607-630. Disponível em: $\quad<$ http://constituicao.direito.usp.br/wp-content/uploads/2003-RLAEC01Principios_e_regras.pdf>. Acesso em: 30 jul. 2017.

XYNOPOULOS, Georges. Le Contrôle de Proportionalité das e Contentieux de la Constitutionnalité et de la Legalité en France, Allemagne et Angleterre. In: CRETTON, Ricardo Aziz. Os Princípios da Proporcionalidade e da Razoabilidade e sua Aplicação no Direito Tributário. Rio de Janeiro: Lumen Juris, 2001.

\section{8 - ANEXOS}

\section{ANEXO I}


ONi

Relatório Justiça em Números 2017

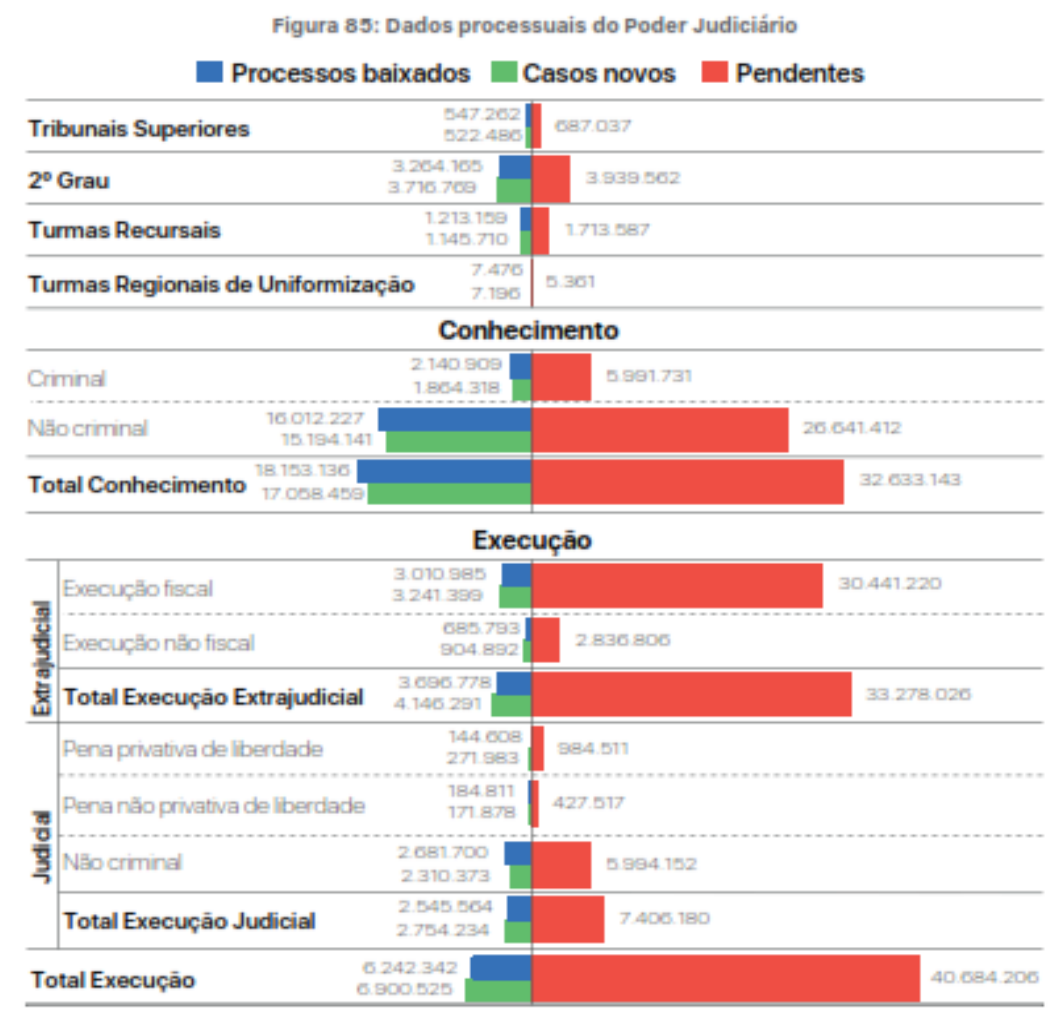

ANEXO II 
Justica

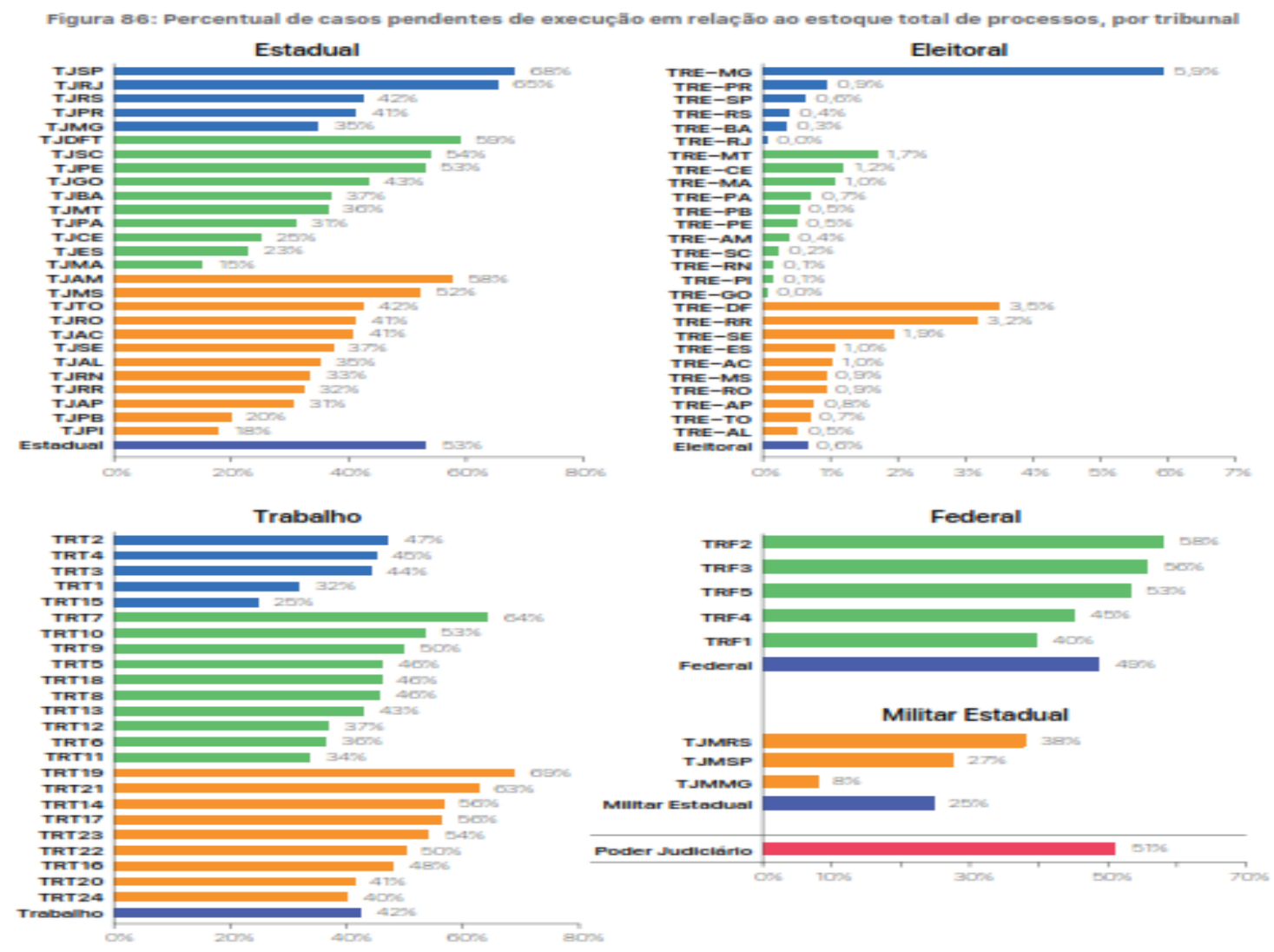

\section{ANEXO III}

avis

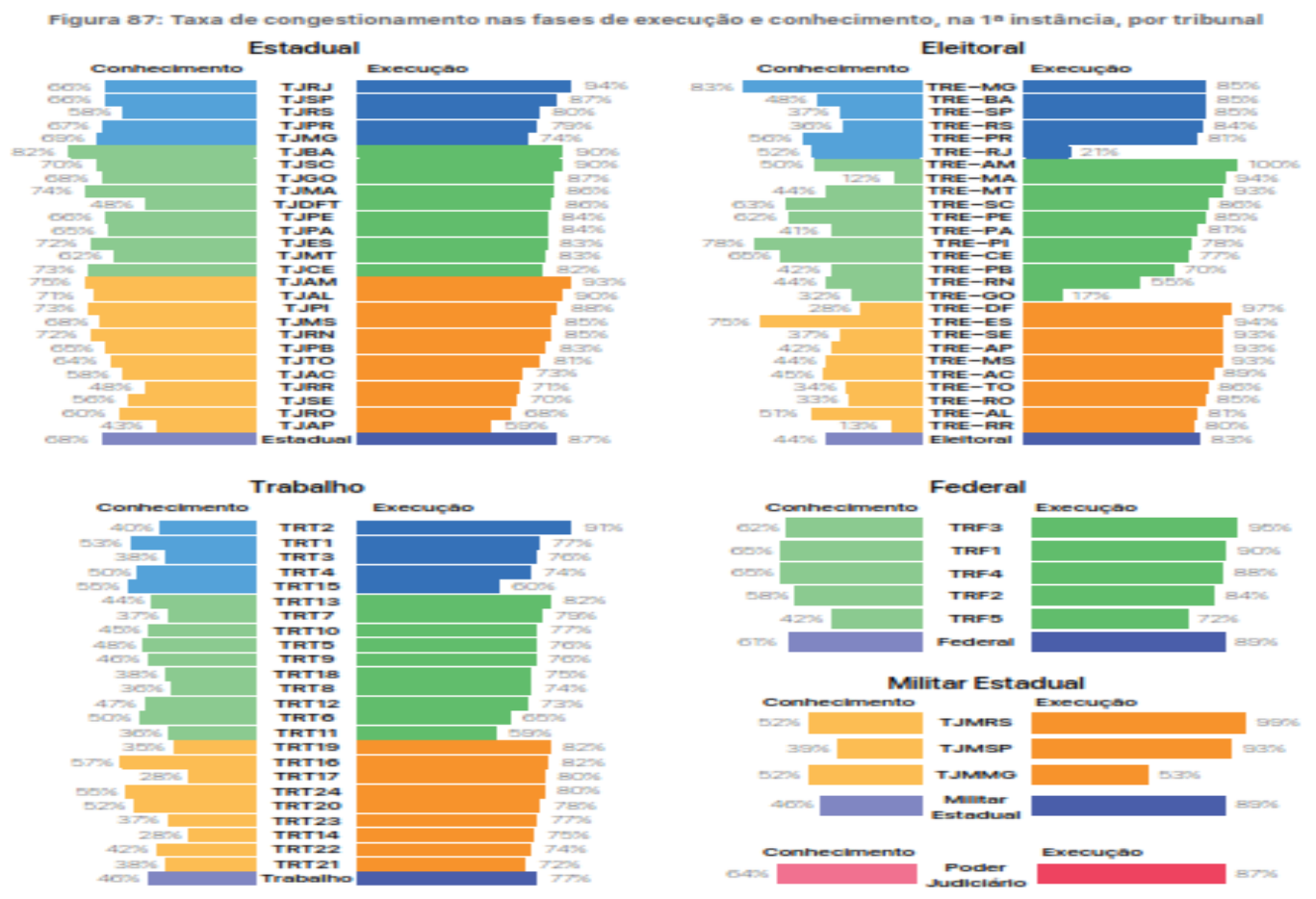




\section{ANEXO IV}

Justiça

Figura 86: Percentual de casos pendentes de execuçắo em relaçăo ao estoque total de processos, por tribunal

Estadual

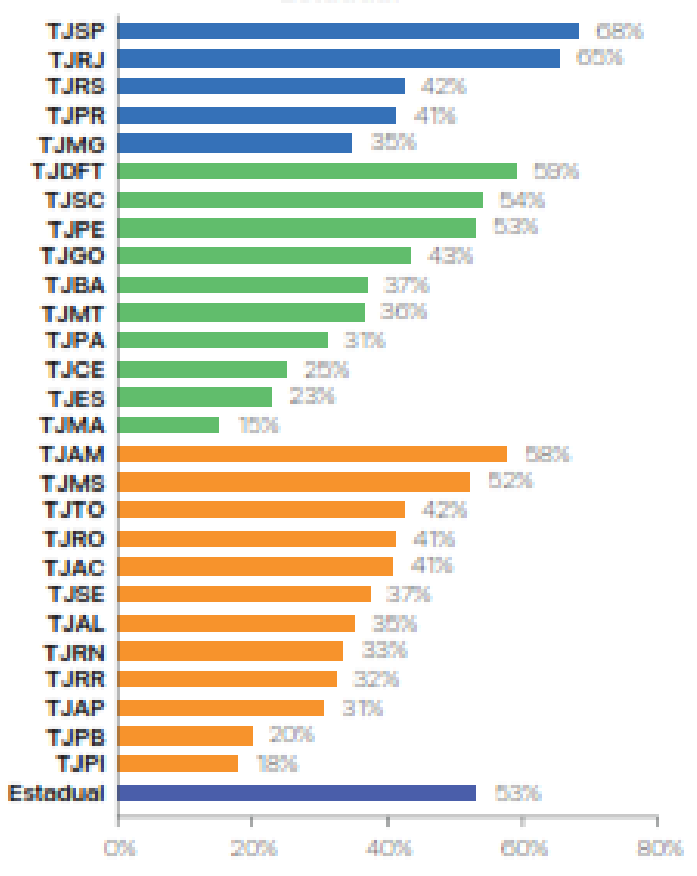

Trabalho

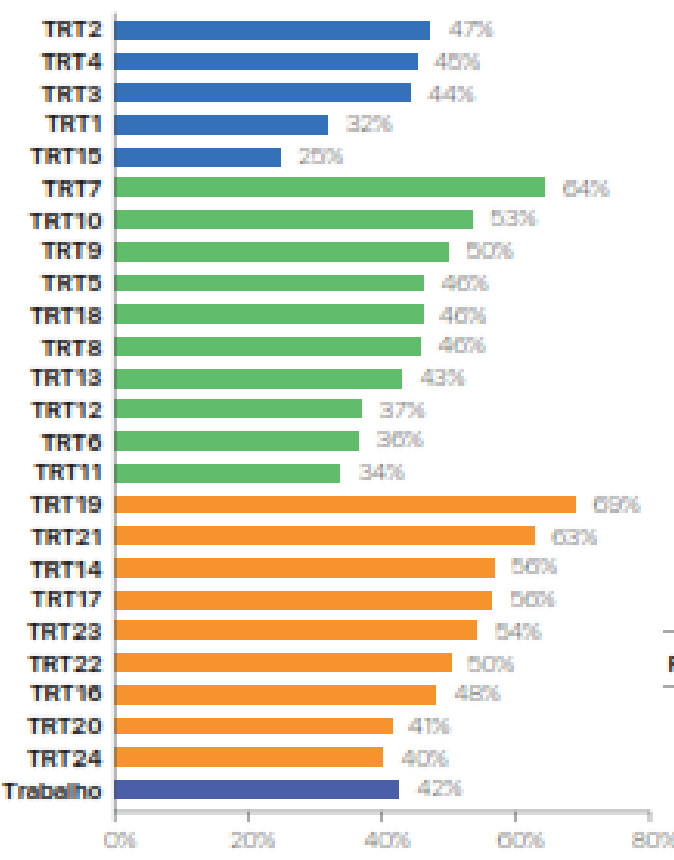

Eleitoral

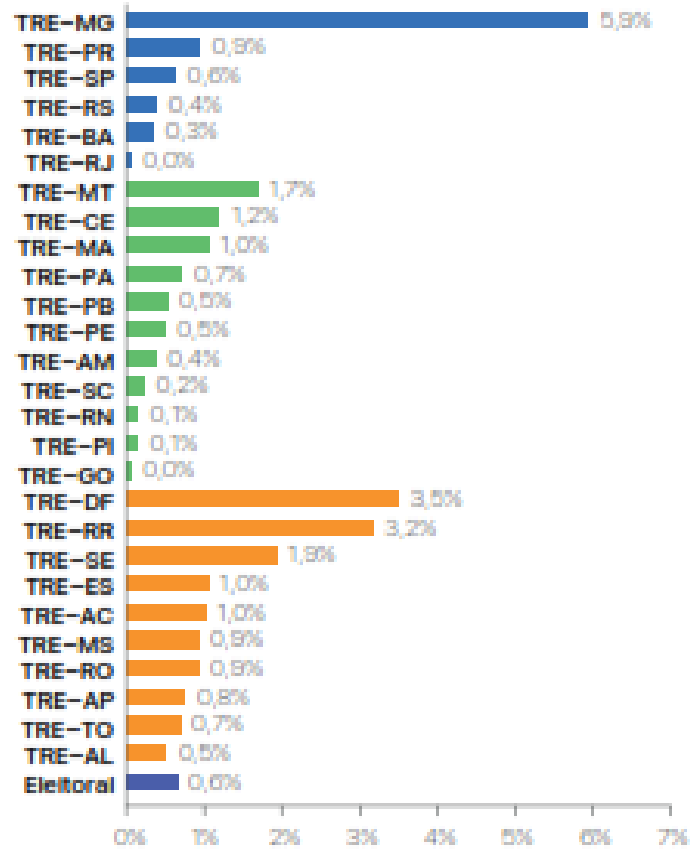

Federal

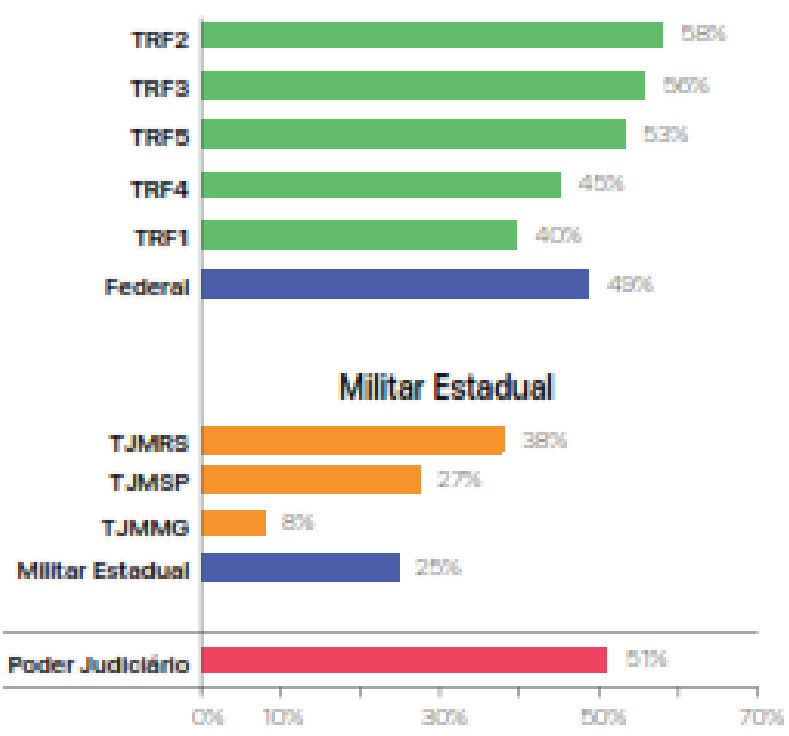

